\title{
Responding to Refugee Crises
}

\section{Lessons from evaluations in Afghanistan as a country of origin}

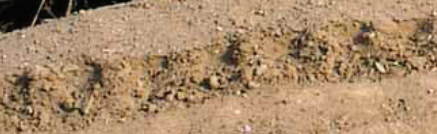

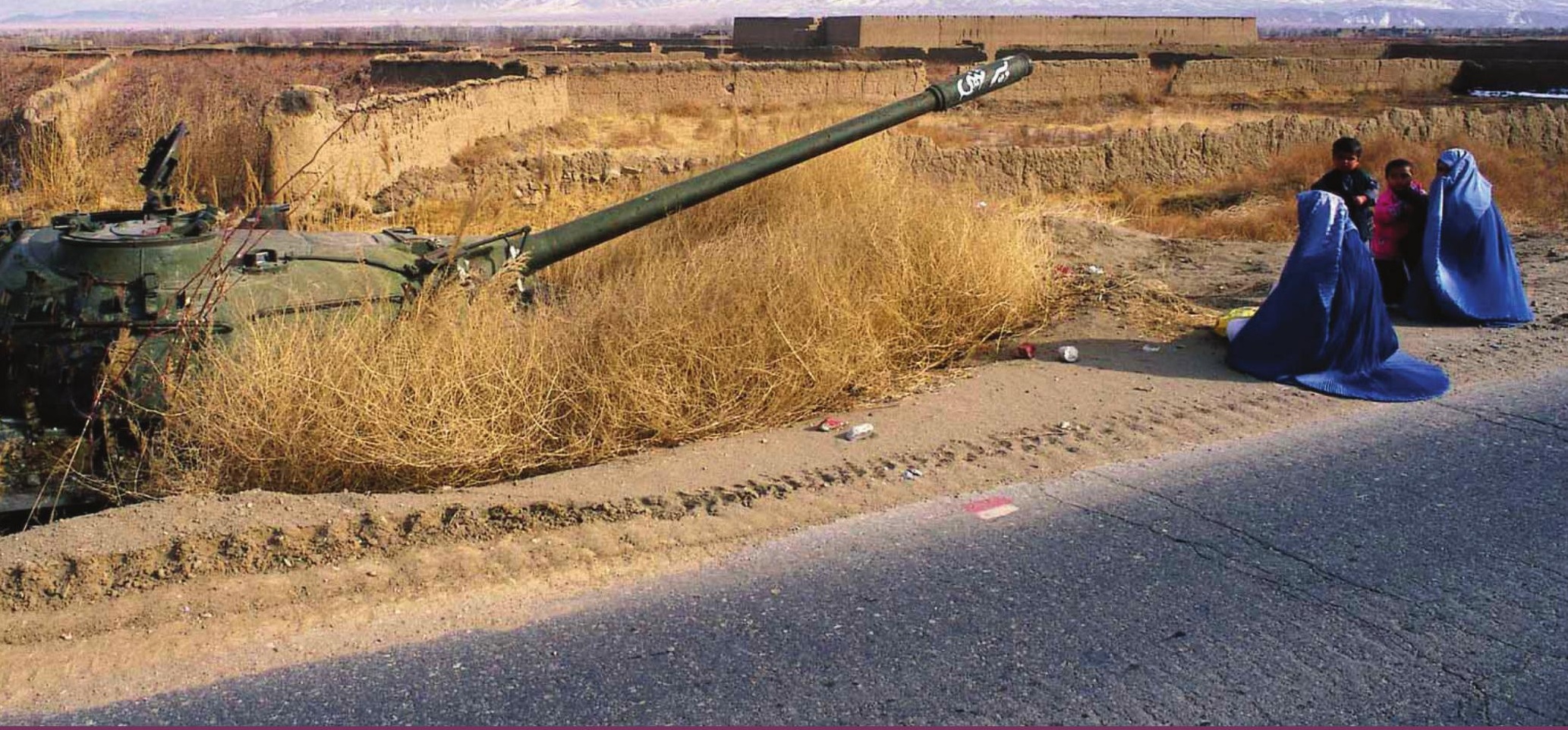


OECD Working Papers should not be reported as representing the official views of the OECD or of its member countries. The opinions expressed and arguments employed are those of the authors.

Working Papers describe preliminary results or research in progress by the author(s) and are published to stimulate discussion on a broad range of issues on which the OECD works.

Comments on Working Papers are welcomed and may be sent to susanna.morrisonmetois@oecd.org, Development Co-operation Directorate, OECD, 2 rue André-Pascal, 75775 Paris Cedex 16, France.

This document and any map included herein are without prejudice to the status of or sovereignty over any territory, to the delimitation of international frontiers and boundaries and to the name of any territory, city or area.

You can copy, download or print OECD content for your own use, and you can include excerpts from OECD publications, databases and multimedia products in your own documents, presentations, blogs, websites and teaching materials, provided that suitable acknowledgement of OECD as source and copyright owner is given. All requests for public or commercial use and translation rights should be submitted to rights@oecd.org.

COPYRIGHT @ OECD 2017

Afghan locals, internally displaced and returnees in the Shomali Plain, Afghanistan.

(C) UNHCR/Piers Benatar 


\section{Foreword}

The OECD Development Assistance Committee (DAC) has recognised that international co-operation and development assistance in relation to forced displacement, refugees, and migration need greater attention. In 2016, the DAC formed a Temporary Working Group on Refugees and Migration.

This working paper is a case study on Afghanistan as a refugee country of origin. The case study looks at whole-of-government efforts by OECD member countries in Afghanistan, specifically looking at how states have co-ordinated development, diplomatic and defense resources in a refugee country of origin. The case study also examines efforts by the international community to promote stability and state building objectives. The case study was undertaken as part of a wider research project on learning from evaluations to improve responses to situations of forced displacement.

The study, Responding to Refugee Crises in Developing Countries: What Can We Learn From Evaluations? provides evidence from evaluations to feed into guidance on better programming that is being developed through the DAC Temporary Working Group. The main paper and three accompanying case studies draw on evaluation findings to highlight some of the key lessons and recommendations for positive change going forward. The main paper and three case studies (Afghanistan, South Sudan and Ethiopia/Uganda) can be found at: www.oecd.org/dac/evaluation/evaluating-refugee-migration.htm.

\section{Acknowledgements}

The author of this working paper is Susanna Morrison-Métois, a policy analyst at the DAC Network on Development Evaluation, working under the supervision of Hans Lundgren, Head of Evaluation in the Review, Engagement and Evaluation Division of the Development Co-operation Directorate.

The author would like to thank the members of the DAC Network on Development Evaluation who supported the research. The project was funded by the evaluation department at NORAD.

Ola Kasneci co-ordinated the preparation of the working paper and case studies for publication, Susan Sachs served as editor and Juria Young of Petit Four Design Ltd was responsible for the graphic design and typesetting. 


\section{Table of contents}

Acronyms and abbreviations $\quad v$

International efforts in Afghanistan: Lessons from a whole-of-government response $\quad 1$

and the creation of Provincial Reconstruction Teams

$\begin{array}{ll}\text { Research notes and citations } & 13\end{array}$

$\begin{array}{ll}\text { References } & 14\end{array}$

\section{Figures}

Figure 1. Growing insecurity poses risks to growth and investment 1

Figure 2. Trend in ODA to Afghanistan since 1970

Figure 3. Allocated US funding to Afghanistan 2

Figure 4. Partial costs of US-led Operation Enduring Freedom and the NATO-led 3 International Security Assistance Force 2001-09

$\begin{array}{ll}\text { Figure 5. Overall stability and resilience trend for MISTI } & 7\end{array}$ 


\section{Acronyms and abbreviations}

$\begin{array}{ll}\text { AOGs } & \text { Armed Opposition Groups } \\ \text { 3D } & \text { Development, Defense, Diplomacy } \\ \text { CERP } & \text { Commander's Emergency Response Program } \\ \text { DAC } & \text { Development Assistance Committee } \\ \text { DANIDA } & \text { Danish International Development Agency } \\ \text { DFATD } & \text { Department of Foreign Affairs, Trade and Development (Canada) } \\ \text { DFID } & \text { Department for International Development (UK) } \\ \text { DIIS } & \text { Danish Institute for International Studies } \\ \text { EU } & \text { European Union } \\ \text { GIROA } & \text { Government of the Islamic Republic of Afghanistan } \\ \text { ISAF } & \text { International Security Assistance Force } \\ \text { MISTI } & \text { Measuring Impact of Stabilization Initiative } \\ \text { NATO } & \text { North Atlantic Treaty Organization } \\ \text { NGO } & \text { Non-governmental organisation } \\ \text { NORAD } & \text { Norwegian Agency for Development Cooperation } \\ \text { ODA } & \text { Official development assistance } \\ \text { OECD } & \text { Organisation for Economic Co-operation and Development } \\ \text { PRT } & \text { Provincial Reconstruction Team } \\ \text { SIGAR } & \text { US Special Inspector General for Afghanistan Reconstruction } \\ \text { UNHCR } & \text { UN Refugee Agency } \\ \text { USAID } & \text { United States Agency for International Development } \\ & \end{array}$


Istalif village, Afghanistan, destroyed by the Taliban.

(c) UNHCR/Piers Benatar

$\lambda$

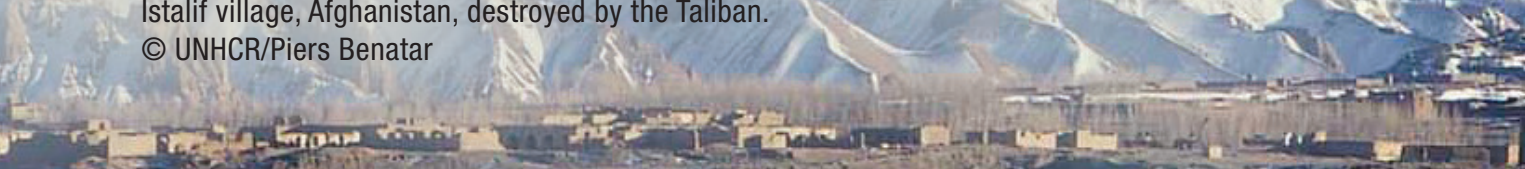

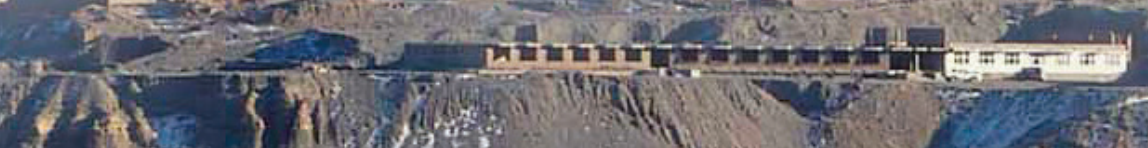

6.

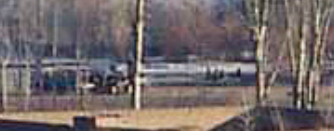

Mcti 2 rectiri,

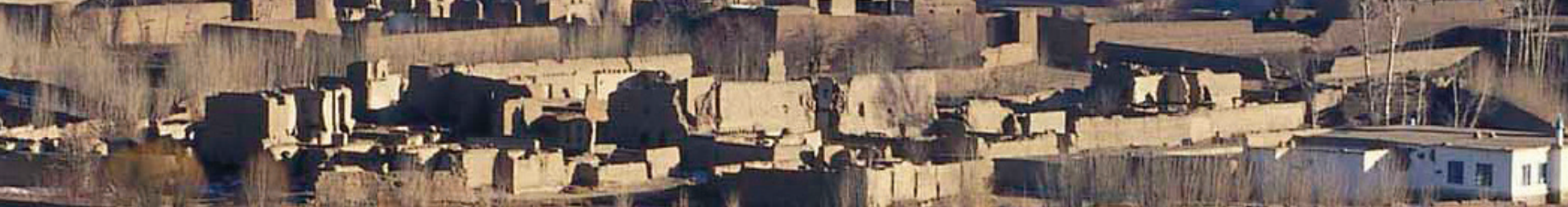

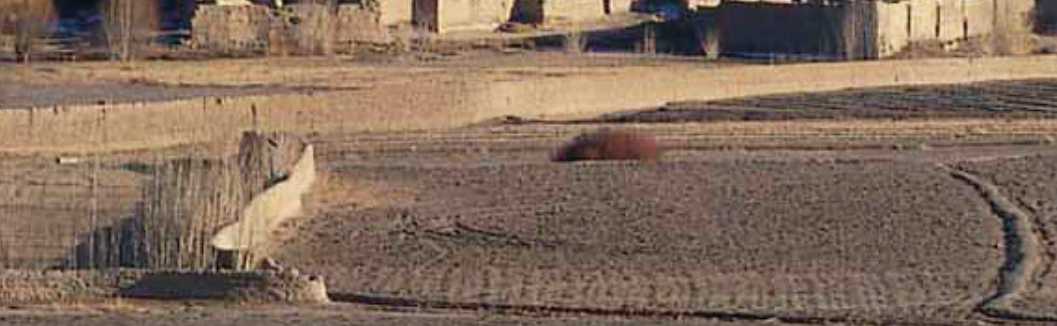
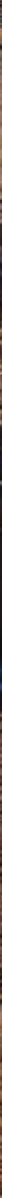

3.

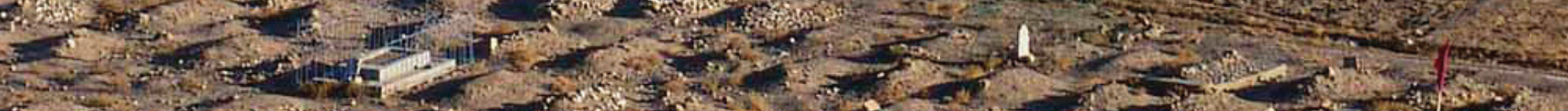

(3)

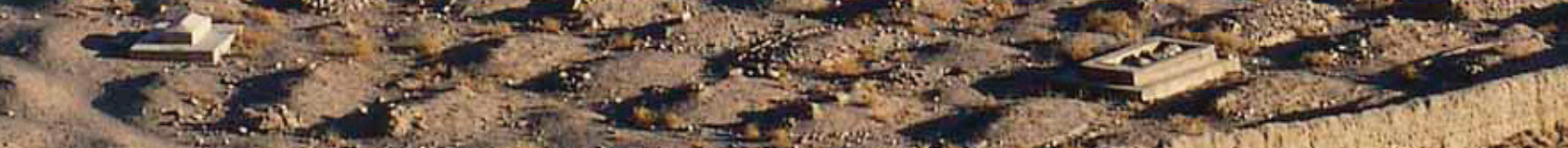

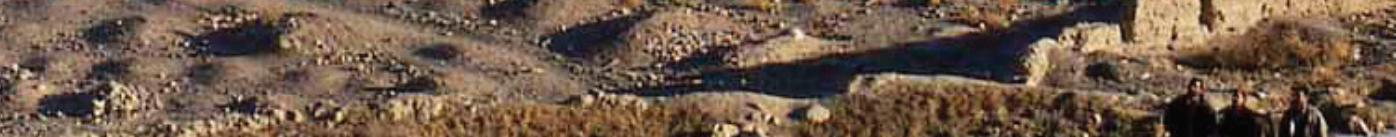
$=2$ 


\section{International efforts in Afghanistan: Lessons from a whole-of-government response and the creation of Provincial Reconstruction Teams}

Afghanistan is one of the top countries of origin in today's refugee crisis. According to UNHCR, Afghanistan is currently the second country of origin, with the Afghan refugee population estimated at 2.7 million at the end of 2015. ${ }^{1}$ Afghanistan has been a major country of origin for over 30 years and for most of this time was the country with the largest refugee population worldwide. ${ }^{2}$ According to some reports, an estimated $75 \%$ of Afghans are thought to have experienced some form of displacement at least once in their lifetimes. ${ }^{3}$ Afghans made up $20 \%$ of the more than one million arrivals by sea and by air into Europe in $2015 .{ }^{4}$ The intensified flow of forcibly displaced Afghans is related to sharp increases in violence. Despite more than 15 years of large-scale international efforts in Afghanistan, the country remains marred by weak rule of law, political fragility and persistent insecurity - circumstances that are likely to continue to discourage many Afghan refugees and migrants abroad to return home voluntarily. ${ }^{5}$ In 2015-16, the number of Afghans moving to Afghanistan from Pakistan and Iran increased sharply, but most of these did not "return" voluntarily. ${ }^{6}$ This large influx, when added to the more than one million internally displaced Afghans, may worsen the political, social and economic conditions in the country (see Figure 1). ${ }^{7}$ UNHCR in particular has raised concerns about the pace of returns in 2016 and has said it "does not promote refugee returns to Afghanistan given the enduring conflict in different parts of the country and its limited absorption capacity". ${ }^{8}$

Figure 1. Growing insecurity poses risks to growth and investment

a. Number of civilian casualties, conflict related

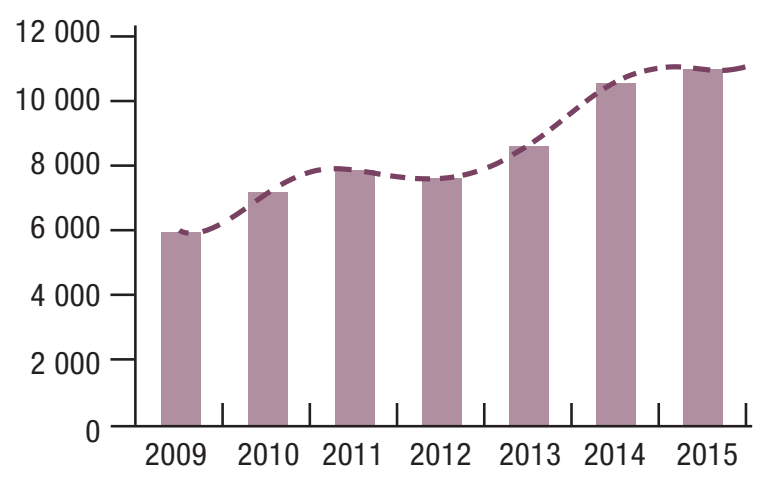

civilian casualties b. Country of Origin of asylum seekers in the

EU-28 member states (thousands of first-time applicants)

Source: World Bank (2016), Afghanistan Development Update, http://documents.worldbank.org/curated/en/953921468196145402/pdf/104871WP-P158556-PUBLIC-AFG-Development-Update-April-2016-final.pdf/. 
This case study looks at efforts by the international community to address the root causes of conflict and help promote stability and state building objectives in Afghanistan since 2001. Many of these efforts drew upon OECD member countries' military, diplomatic and development resources. The aim of this case study is to look at the use of whole-of-government approaches in a major refugee country of origin.

Afghanistan has been among the top recipients of official development assistance (ODA) in the last 15 years, and currently tops the list of ODA recipient countries, according to the most recent figures. ${ }^{9}$ International actors reportedly have spent over USD 130 billion in Afghanistan since 2002 including on security, governance and development, civilian operations, counter-narcotic initiatives and humanitarian aid. ${ }^{10}$ The United States has provided approximately USD 115 billion of this total (see Figure 3). ${ }^{11}$ In July 2016, at a summit in Warsaw, NATO nations committed USD 5 billion a year to fund Afghan forces until 2020 and agreed to maintain current troop numbers. Donors also pledged an additional USD 15.2 billion for Afghanistan for four years at a donors' conference in Brussels on 5 October 2016, with the European Union pledging EUR 1.2 billion. ${ }^{12}$ The donors' actions came days after the EU signed an agreement with Afghanistan, on 2 October 2016, regarding the return of Afghan citizens denied the right to stay in the EU. This "Joint Way Forward on migration issues" was agreed following intense negotiations between the EU and the government of Afghanistan. ${ }^{13}$ Bilateral agreements then followed between Germany and Afghanistan and between Finland, Sweden and Afghanistan (although the Afghanistan National Assembly subsequently rejected the agreement with Sweden). ${ }^{14}$ Figures 2, 3 and 4 provide more detail on spending by international actors in Afghanistan.

Figure 2. Trend in ODA to Afghanistan since 1970

USD billion, 2013 prices and exchange rates, 3-year average net ODA receipts

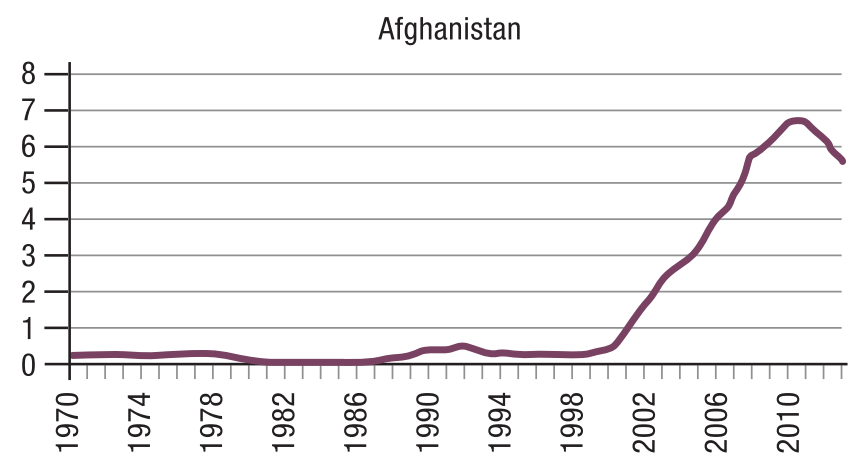

Source: OECD, 2016, www.oecd.org/dac/stats/documentupload/4\%20 Asia\%20-\%20Development\%20Aid\%20at\%20a\%20Glance\%202016.pdf.
Figure 3. Allocated US funding to Afghanistan

USD billion, October 2002 - June 2016

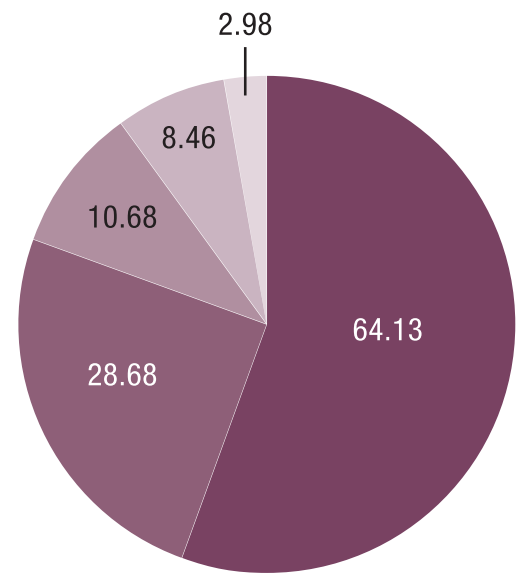

Security

Governance and development

Civilian operations

Counter-narcotics initiatives

Humanitarian aid

Source: SIGAR, (2016a), Quarterly Report to the United States Congress, https://www.sigar.mil/pdf/ quarterlyreports/2016-07-30qr.pdf. 
Since 2001, Afghanistan has served as the testing ground for the whole-of-government and 3D approaches of many OECD countries. ${ }^{15}$ In October 2001, following the September 2001 terrorist attacks in the United States, the US led a military coalition to topple the Taliban in Afghanistan. In December 2001, the UN Security Council passed Resolution 1386 establishing the International Security Assistance Force (ISAF). In the summer of 2002, the US proposed the concept of Provincial Reconstruction Teams (PRTs). ${ }^{16}$ Other countries including Australia, Canada, Denmark, Finland, France, Germany, Hungary, Italy, Lithuania, New Zealand, Norway, Poland, Romania, Korea, Spain, Sweden, the Czech Republic, the United Kingdom and Turkey went on to lead or contribute personnel to PRTs in Afghanistan, to bring together their development, diplomatic, defence and other actors. Over the years, there has been much debate around the application of whole-of-government and 3D approaches as operationalised in Afghanistan with the creation of PRTs.

Figure 4. Partial costs of US-led Operation Enduring Freedom and the NATO-Ied International Security Assistance Force 2001-09

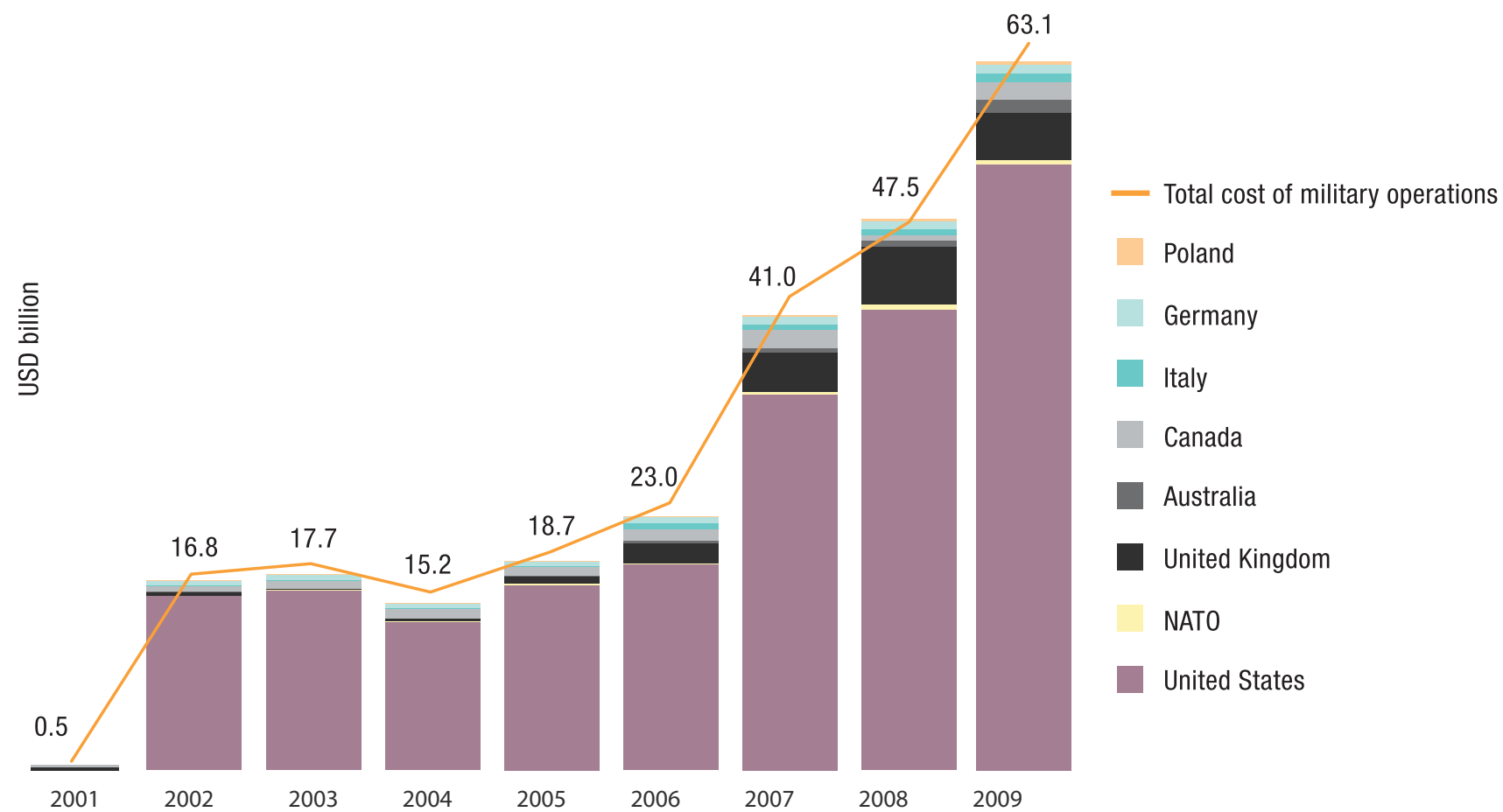

Source: Poole, L. (2011), http://afghandata.org:8080/xmlui/bitstream/handle/azu/15274/azu_acku_pamphlet_hv555_a3_p66_2011_w. pdf? sequence=1\&isAllowed=y.

Evaluations of whole-of-government programmes in Afghanistan and other fragile contexts specifically questioned the efficacy of the PRTs. ${ }^{17}$ A 2013 analysis conducted by the Danish Institute for International Studies (DIIS), which drew on dozens of evaluations that had been commissioned by major donors, noted that many donor governments faced challenges because civil and military entities operating in the same spaces had divergent interests, differing approaches and high transaction costs. ${ }^{18}$ There were often "interdepartmental cultural clashes and personality differences" 19 which undermined the PRT's effectiveness. ${ }^{20}$ The study cited evaluations to suggest that the whole-of-government approach as applied in Afghanistan may have put greater emphasis on "particular security-political aims" than on development priorities and good practices such as the "do no harm" principle, and at times tested the boundaries around the definitions of ODA. ${ }^{21}$ 
Furthermore, there is some evidence that the PRTs were replicating activities traditionally done by humanitarian organisations and NGOs. ${ }^{22}$ A 2007 evaluation of Finnish aid to Afghanistan found that the development tasks of the PRTs "have not been well-prepared or coordinated with the national priorities of Afghanistan. There is also reason to believe that the cost-effectiveness is low as military deployment itself is expensive". ${ }^{23}$ The DIIS study and other evaluations reviewed as a part of this research also suggested that many of the PRTs deliberately blurred civil-military boundaries and frequently implemented short-term reconstruction projects that evaluators have since labelled as unsustainable. ${ }^{24}$ More worrisome still is the finding of a 2012 evaluation of Denmark's development support to Afghanistan, conducted by the Evaluation Department of the Ministry of Foreign Affairs of Denmark, which looked specifically at education assistance.

In areas where the international military and PRT provide educational assistance, often playing a significant role in rehabilitating critically needed infrastructure which Government has been unable to deliver, schools may be more vulnerable to attack, precisely because they have been constructed by foreign forces.

International donors and aid partners have provided much support to education over the past 10 years. However, where this has been channelled through direct partnerships outside the Afghan Government it has thereby compromised state capacity and missed the opportunity to increase legitimacy. To this extent it has failed to address the conflict dynamics outlined and reduced its assistance to the Afghan State. ${ }^{25}$

A 2016 evaluation analysed the totality of Norway's engagement in Afghanistan from 2001-14 including the PRT led by Norway in Faryab province, joint intelligence activities including Norwegian intelligence's role in the Afghan Crisis Response Unit, and Norwegian diplomatic efforts to promote a political solution. Its findings were consistent with the overall conclusions of the Danish government's evaluation. The Norway evaluation found that international actors had a limited understanding of local conditions, culture and local conflict dynamics. It also found that the international coalition prioritised short-term security goals, often thereby increasing corruption and abuse, through activities and operations that were at times internally inconsistent or contradictory. ${ }^{26}$ The Norwegian evaluation concluded that state-building efforts based on large-scale military efforts, large international resource flows and weak existing state institutions are difficult. ${ }^{27}$ A 2015 evaluation of Canada's efforts in Afghanistan echoed some of these concerns: "understanding the political economy and main drivers of conflict and fragility received relatively little attention in Canada's Afghanistan Development Program, but Canada was not exceptional in this regard." ${ }^{28}$ The situation improved to some degree with changes made to Canada's whole-of-government approach in 2011 following the withdrawal of Canadian troops from Kandahar, but the evaluation found that "understanding remained incomplete. The principles for engagement in fragile and conflict-affected states call for a thorough understanding of the context, including the conflict. In practice, the international community, Canada included, was more focused on implementation." ${ }^{29}$ 

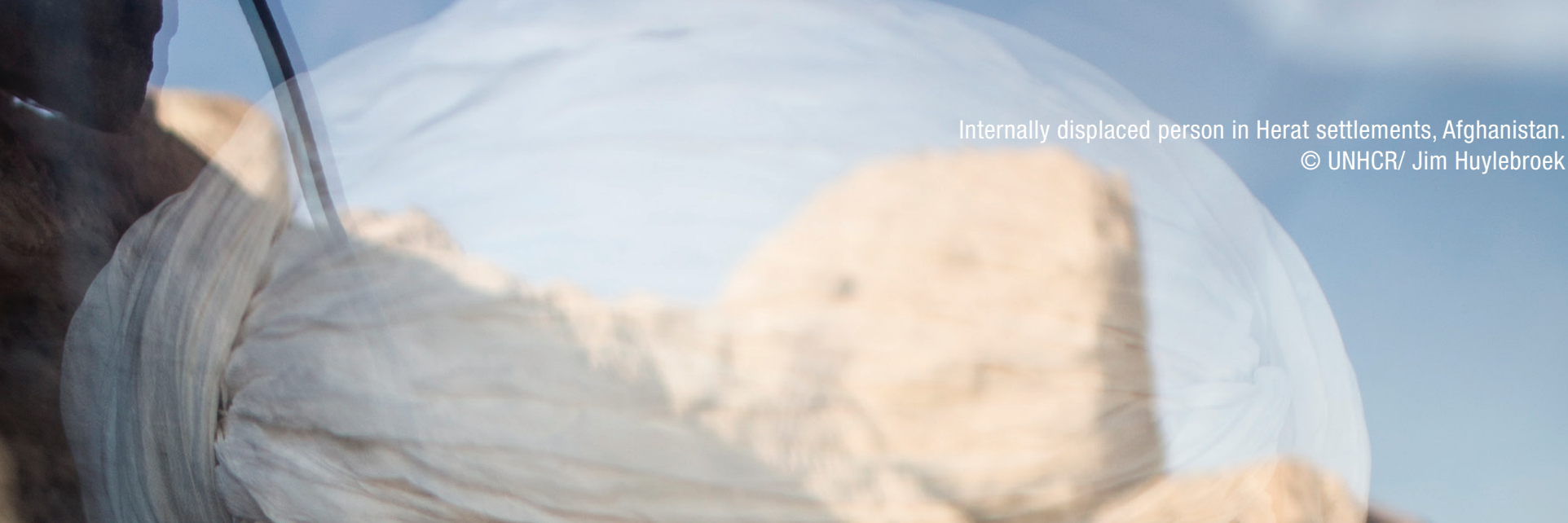
(c) UNHCR/ Jim Huylebroek
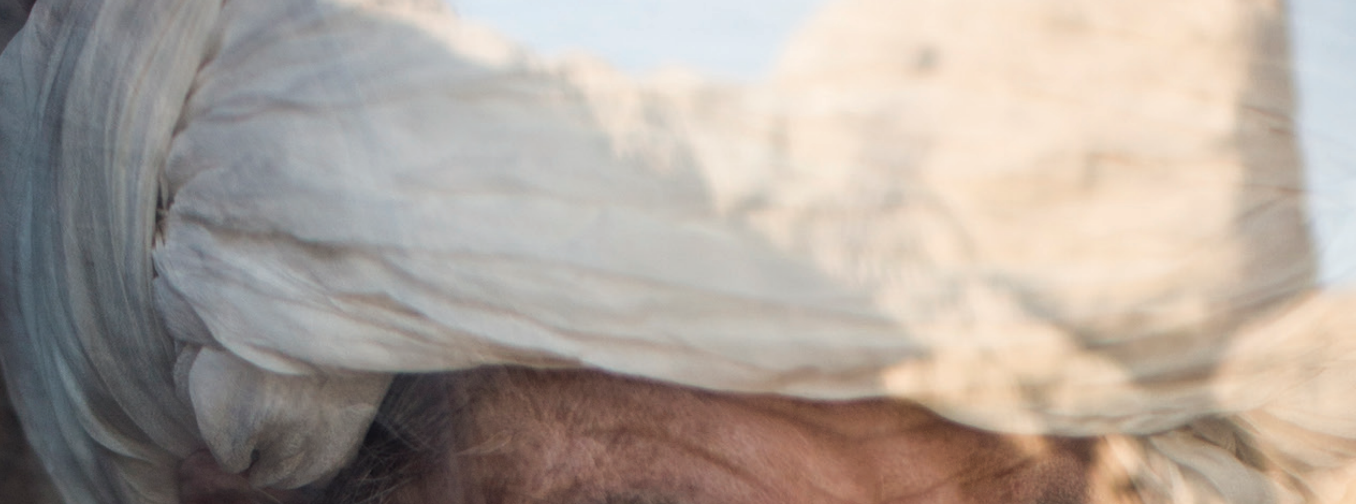

Nos
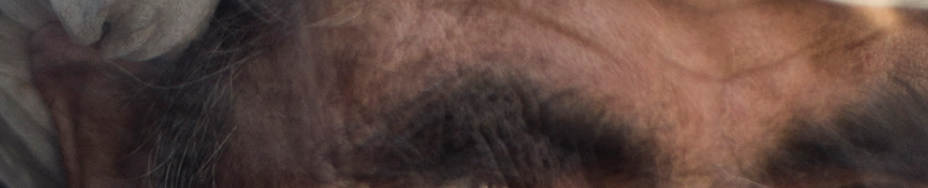

anceit
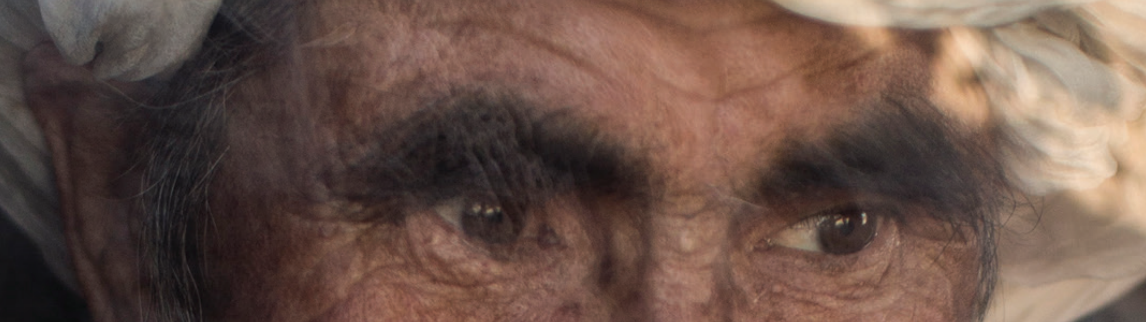
(3) -2
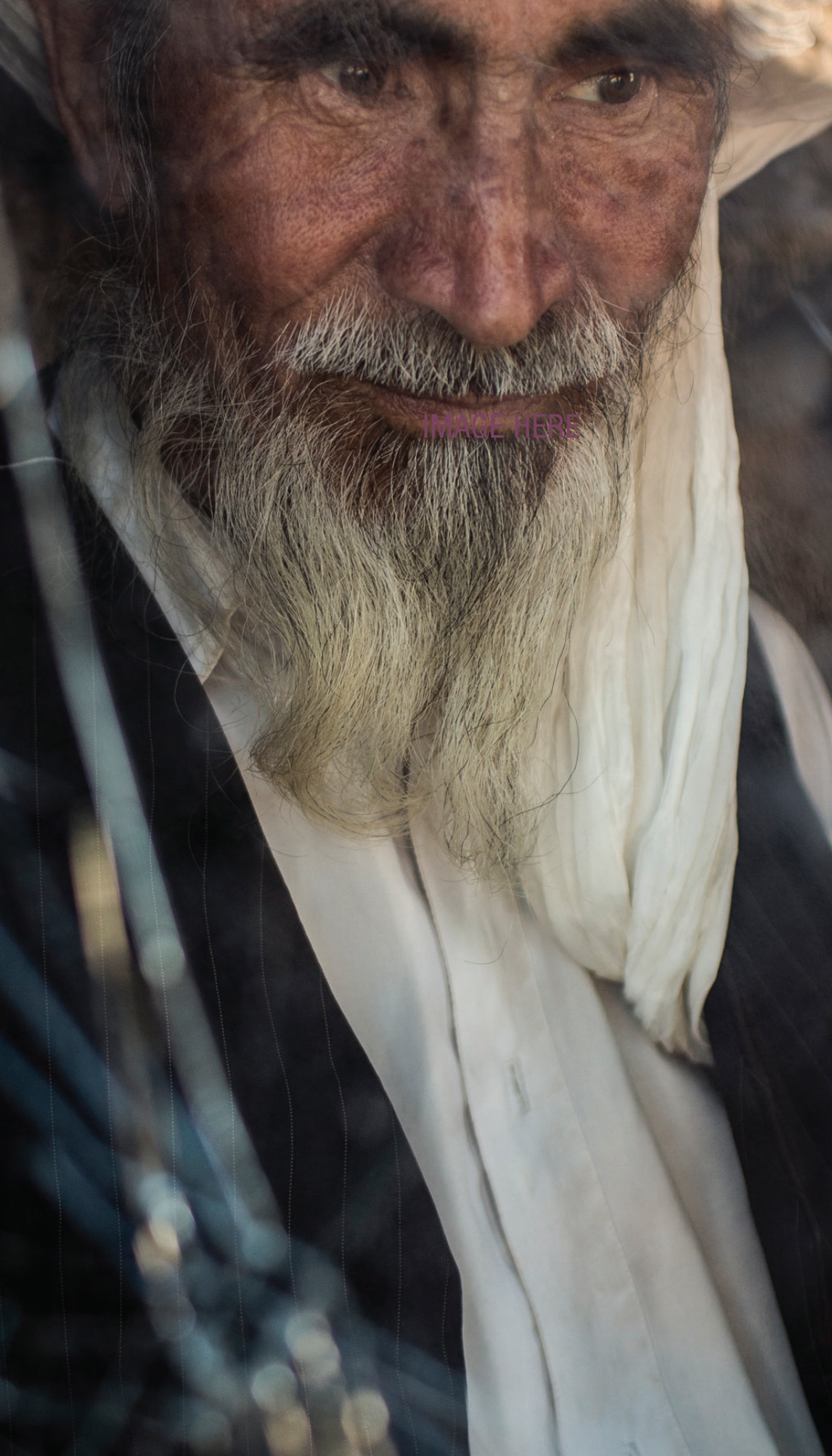

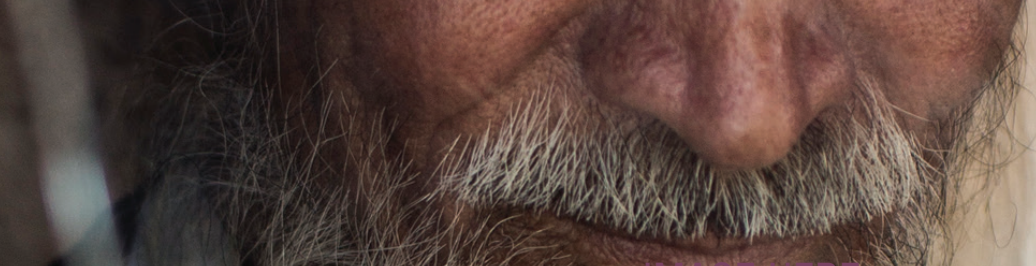
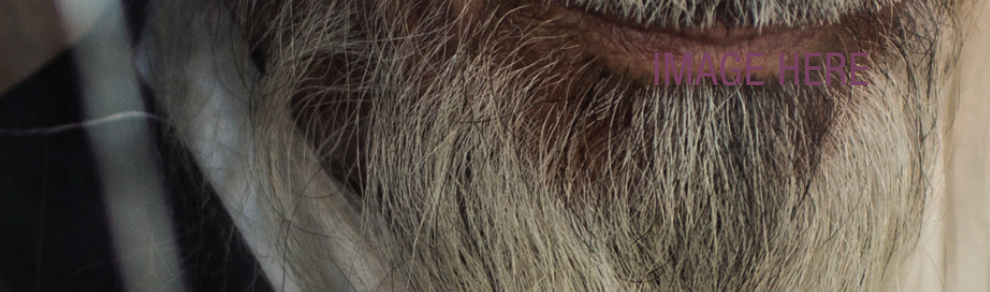
The PRT approach in Afghanistan also reflects an overall trend of increasing politicisation of aid, with countries directing ODA funds to areas where their militaries are also deployed. ${ }^{30}$ Humanitarian actors have been highly vocal in their opposition to military actors taking on development and humanitarian objectives, arguing that such actions lead to the reduction of "humanitarian space" and directly violate key humanitarian principles such as neutrality and impartiality that for decades have formed the bedrock of humanitarian action. Canada's 2015 evaluation, for example, bluntly acknowledged this concern and considered it an unintended consequence: "The 'blurring' of lines related to the politicization and militarization of humanitarian assistance has led to a reduction of humanitarian space in Afghanistan. Humanitarian actors have been unable to secure access to all parts of the country." ${ }^{31}$ Similarly, an interagency assessment by USAID in 2006 said that early on, "the lack of explicit guidance led to confusion about civilian and military roles in the U.S. led PRT." 32 There have been notable efforts to establish civil-military guidelines (such as those agreed by the UN Assistance Mission in Afghanistan and by ISAF), but the impacts of these initiatives are unclear. ${ }^{33}$ Meanwhile some countries, such as Norway, made conscious decisions to keep clearer divisions between military and civilian activities in an effort to safeguard development projects. ${ }^{34}$

Another good practice that emerges from reports is Australia's establishment of a statement of "principles and protocols" for its whole-of-government response in Afghanistan. The statement of principles helped the Australian government establish guidelines for civilian and military collaboration and clarified issues of chain of command and reporting requirements. ${ }^{35}$ Australia's lessons learned on its whole-of-government experience in Afghanistan noted that such guidelines and principles need to be established from the onset for future interventions and that the protocols should aim to "define the working relationships and responsibilities and expectations of the different services and agencies, and be as clear as possible on the chain of command and management responsibilities of the respective agencies in the field." 36 The 2016 Australian evaluation recommended that the principles and protocols be reviewed annually and adjusted as needed.

Efforts by international actors in fragile and conflict-affected countries like Afghanistan have often started from the assumption that joining development, defence and diplomatic actors through joint programming and focusing on quick wins will help reinforce support for the state as a legitimate actor (i.e. by helping to eliminate "ungoverned spaces"), improve governance and help lead to stability. ${ }^{37}$ Evaluation evidence from Afghanistan suggests that international actors' efforts may have actually undermined the population's support for the government of Afghanistan in some cases. ${ }^{38}$

Laudably, the US government has shown a strong interest in learning and has created a well-funded monitoring and evaluation project in Afghanistan to learn from interventions and programmes designed to promote stability and resilience at district and village level. The USD 21 million project, known as the USAID/Afghanistan Measuring Impact of Stabilization Initiative (MISTI), is "the largest and most comprehensive trends analysis and impact evaluation of stabilization interventions that the U.S. Government has ever undertaken". ${ }^{39}$ Research for the MISTI project involved a perceptions survey with more than 190000 household interviews in Afghanistan and an impact evaluation looking at the effects of the projects' activities on stability indicators. The MISTI project yielded an enormous set of data for analysis. Some of the data have led to findings that challenge assumptions underlying international stabilisation efforts. For example, the Wave-5 MISTI report and impact evaluation, found that overall stability and resilience trend lines across the 55 Afghan districts being monitored as part of the project were largely flat (see Figure 5), thereby questioning if the activities had the desired results in terms of increasing stability and resilience over time. ${ }^{40}$ 
Figure 5. Overall stability and resilience trends for MISTI

Trends in stability and resilience are measured by the change in index scores over the five waves of the MISTI Survey.

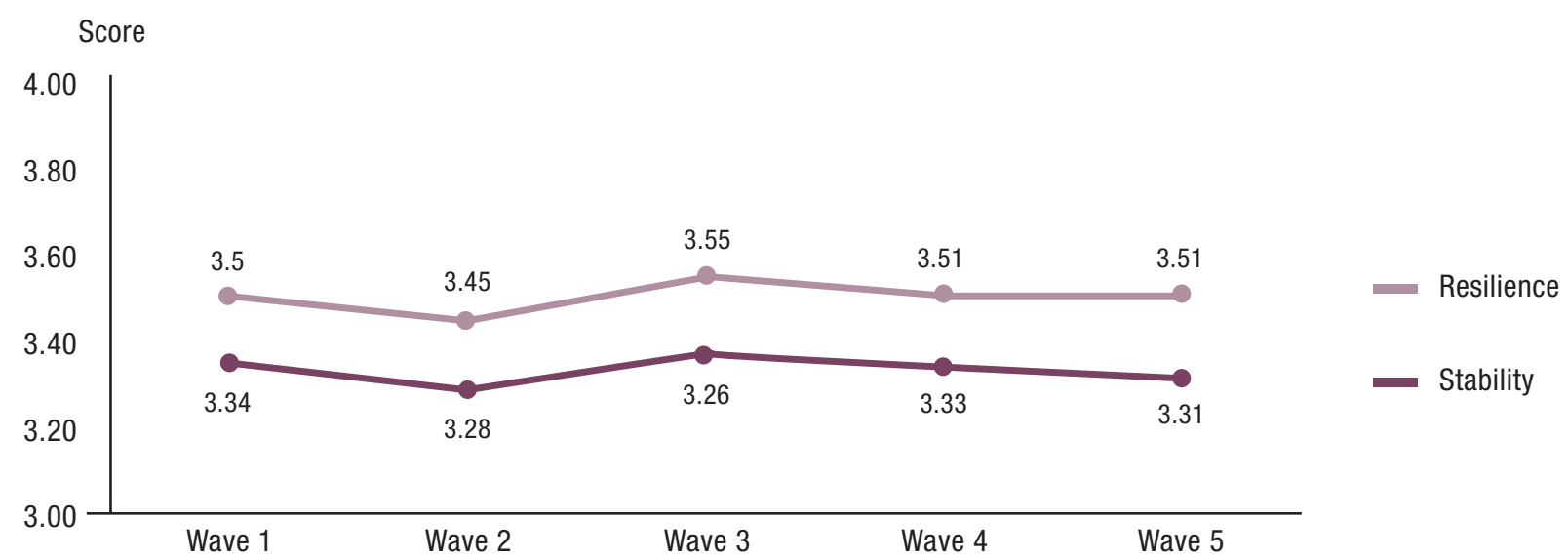

Source: USAID/MSI (2015), http://pdf.usaid.gov/pdf_docs/pa00ks3x.pdf.

More surprisingly, the MISTI impact evaluation found that stabilisation activities actually decreased stability in villages where projects were implemented in some of the time periods being assessed, although in previous waves of the study (earlier periods) the impacts had been positive. ${ }^{41}$ The report attributed this in part to internal factors such as the frustrations of Afghan villagers and their high expectations, and in part to external factors such as the withdrawal of ISAF forces. It also highlighted the persistent "divisions between traditional leadership and formal government institutions". ${ }^{42}$ There were other unexpected and nuanced findings. For instance, the report found that "stabilization programming actually had the perverse effect of increasing support for the Taliban in Taliban controlled villages". ${ }^{43}$ This worrisome finding led to the recommendation that "interventions should not be implemented in areas that are controlled by the Taliban because doing so helps the Taliban win hearts and minds". ${ }^{44}$ The report also suggested that "combining soft and hard interventions had the most positive impacts", but that "violence increased in the short term after stabilization interventions". ${ }^{45}$ According to the report, "this finding provides clear evidence that the Taliban and other A0Gs [armed opposition groups] target villages because of stabilization interventions". ${ }^{46}$

The MISTI Wave 5 report also discussed trends in four of the components of stability and resilience that the project monitored: local governance, community cohesion, government capacity and quality of life. ${ }^{47}$ The report found that stabilisation programming had reduced support for the Taliban up until March-May 2014, but noted an unexpected increase in support for the Taliban in the June-November 2014 reporting period.

Among its other interesting findings were these:

- "Soft stabilization programming should include literacy and empower women (e.g. vocational training) because these types of activities have the greatest impact on reducing support for the Taliban and other anti-government elements."

- "Programming focused solely on boosting incomes in the short term, such as cash for work activities, should not be implemented because of the risk of increasing support for the Taliban. In particular, efforts to improve per capita income via development projects without prior assessment of territorial control by the Taliban or GIRoA [Government of the Islamic Republic of Afghanistan] may have detrimental effects." 48 
Overall, MISTI, which is the largest US government-funded project ever to monitor the impact of stabilisation programming, raises a number of questions about many of the principal assumptions underlying stabilisation interventions' programme logics and rationales.

Other evaluations have also suggested that international assistance may have had destabilising effects in Afghanistan, despite short-term achievements. The 2015 evaluation of Canada's Afghanistan Development programme, for example, found:

There was evidence of unintended impacts of the aid provided by the international community in Afghanistan - both destabilizing effects, including the shrinking of humanitarian space, and stabilizing effects, especially in urban environments where access to health and education facilities increased. With the benefit of hindsight, it can be concluded that sustainability of development results - in particular, building the necessary capacity and local ownership requires more time than foreseen in military stabilization theories. ${ }^{49}$

Experiences from the PRT approach in Afghanistan therefore question the underlying logic that is still commonly heard in policy debates about links between quick-win development activities and long-term stabilisation.

Additionally, there are some serious concerns about the sustainability of programmes in Afghanistan that sidestepped local authorities. ${ }^{50}$ A meta-evaluation of USAID projects from 2010-15 found that despite the cross-cutting US government policy to promote Afghan leadership and ownership to help ensure that Afghans take the lead role in development, this had often not happened in practice. Specifically the meta-evaluation found that:

[S]everal of the USAID projects did little to involve local or ministerial counterparts in project planning or implementation. This may have been the case because, in previous years, USAID focused on delivering services to the public as soon as possible for stabilization purposes. Some projects may have knowingly sidelined Afghan ministries and other counterparts because of their limited capacity at the time. ${ }^{51}$

Evaluations and lessons learned documents on US engagement in Afghanistan have found repeatedly that efforts to show short-term results, with the belief that quick results will help stabilisation, have undermined long-term development planning, often by side-lining key Afghan interlocutors. The 2014 USAID MISTI program evaluation suggested that US government-sponsored aid projects in Afghanistan may have had unintended negative effects when large inflows of funds were quickly spent ("pushes for programming") without due regard for the often limited absorptive capacity of local institutions, with concerns about potentially fuelling corruption and "a heightened risk of doing more harm than good". ${ }^{52}$ A 2009 USAID evaluation of corruption in Afghanistan found:

Afghans believe that international assistance is also corrupt, due to inefficiencies in high-cost delivery through international organizations, NGOs, and firms. Afghan perceptions of international "corruption" criticize the high pay and overheads for NGOs, contractors, consultants, and advisors as a form of corruption, irrespective of whether or not the applicable rules were followed in IC [international community] contracting. For its part, the Afghan government views much aid as corrupt simply because the resources are channelled outside the national budget and outside of their control. ${ }^{53}$ 
Concerns about corruption were also raised in the Australian Civil-Military Centre lessons learned report on its whole-of-government approach. The report noted that it was not necessarily clear in Afghanistan who had the mandate and capacity to co-ordinate international efforts, but that the Afghan government was able to approve the Afghanistan National Development Strategy in 2008 that outlined a strategy for security, governance, economic growth and poverty reduction. ${ }^{54} \mathrm{~A}$ key feature of the strategy was the "preference for aid to be channelled through the central government rather than directed to provinces to the interests of donors". ${ }^{55}$ However, the Australian report found, "at the same time, military forces were spending enormous sums of money on local roads, bridges and so on, which were outside the purview of normal aid processes. Indeed national government has a great difficulty in determining how much was being spent, and on what, by their forces. Not surprisingly, corruption amongst local government officials and power brokers became an issue". ${ }^{56}$

There is strong evidence that international efforts in Afghanistan failed to effectively combat corruption and may have further fuelled it. A 2016 report on corruption by the US Special Inspector General for Afghanistan Reconstruction (SIGAR) looked at US government (Department of Defense, State Department, Department of Justice and USAID) efforts to combat corruption. The report identified five main findings:

1. Corruption undermined the U.S. mission in Afghanistan by fuelling grievances against the Afghan government and channelling material support to the insurgency.

2. The United States contributed to the growth of corruption by injecting tens of billions of dollars into the Afghan economy, using flawed oversight and contracting practices, and partnering with malign powerbrokers.

3. The U.S. government was slow to recognize the magnitude of the problem, the role of corrupt patronage networks, the ways in which corruption threatened core U.S. goals, and that certain U.S. policies and practices exacerbated the problem.

4. Even when the United States acknowledged corruption as a strategic threat, security and political goals consistently trumped strong anticorruption actions.

5. Where the United States sought to combat corruption, its efforts saw only limited success in the absence of sustained Afghan and U.S. political commitment. ${ }^{57}$

Furthermore, a number of well-funded programmes and projects in Afghanistan have failed to show uptake and continued development benefit, with evaluations often citing low sustainability. A 2013 lessons learned report for USAID on Provincial Reconstruction Teams (PRTs) in Afghanistan during the 2009-12 period found that "billions of dollars" were spent in this period through the US military's Commander's Emergency Response Program (CERP) and donor development programmes "with little reflection on decades of experience showing the critical link between local buy-in, institutional absorptive capacity, sustainability, and/or lasting development impact of the projects". The Canadian effort in Afghanistan similarly concluded that "while constructive steps were taken to link relief, reconstruction and development, including by giving the Afghanistan Program direct responsibility for humanitarian response, in practice there was limited success in doing so". 59 
Overall, evaluative evidence and lessons learned processes have questioned the assumption that bringing together development, defence and diplomatic actors in multi-disciplinary teams, structured as the PRTs were in Afghanistan, will necessarily result in enhanced security gains and better long-term outcomes. They highlighted issues over "turf wars" for control and resources; conflicting interests and organisational cultures; and a persistent lack of long-term development planning that was likely related, in part, to the political attention focused on visible, short-term results. This is not to suggest that ODA cannot play an important role in supporting countries' transitions out of violence and conflict, but does suggest that operational models to implement whole-of-government approaches may need more work. There is some limited evidence that the efforts of PRTs and actions of joint military-development teams may be more effective when they focus on security sector reform rather than on assistance projects. ${ }^{60}$ The international community would do well to heed lessons from the Afghan context so as not to repeat similar errors in other fragile and conflict-affected contexts, many of which are among the main countries of origin in today's refugee crisis.

People from Ghor and Badghis provinces displaced by fighting between Taliban and government forces sit near their homes at Minarets Informal Settlement in Herat, Afghanistan.
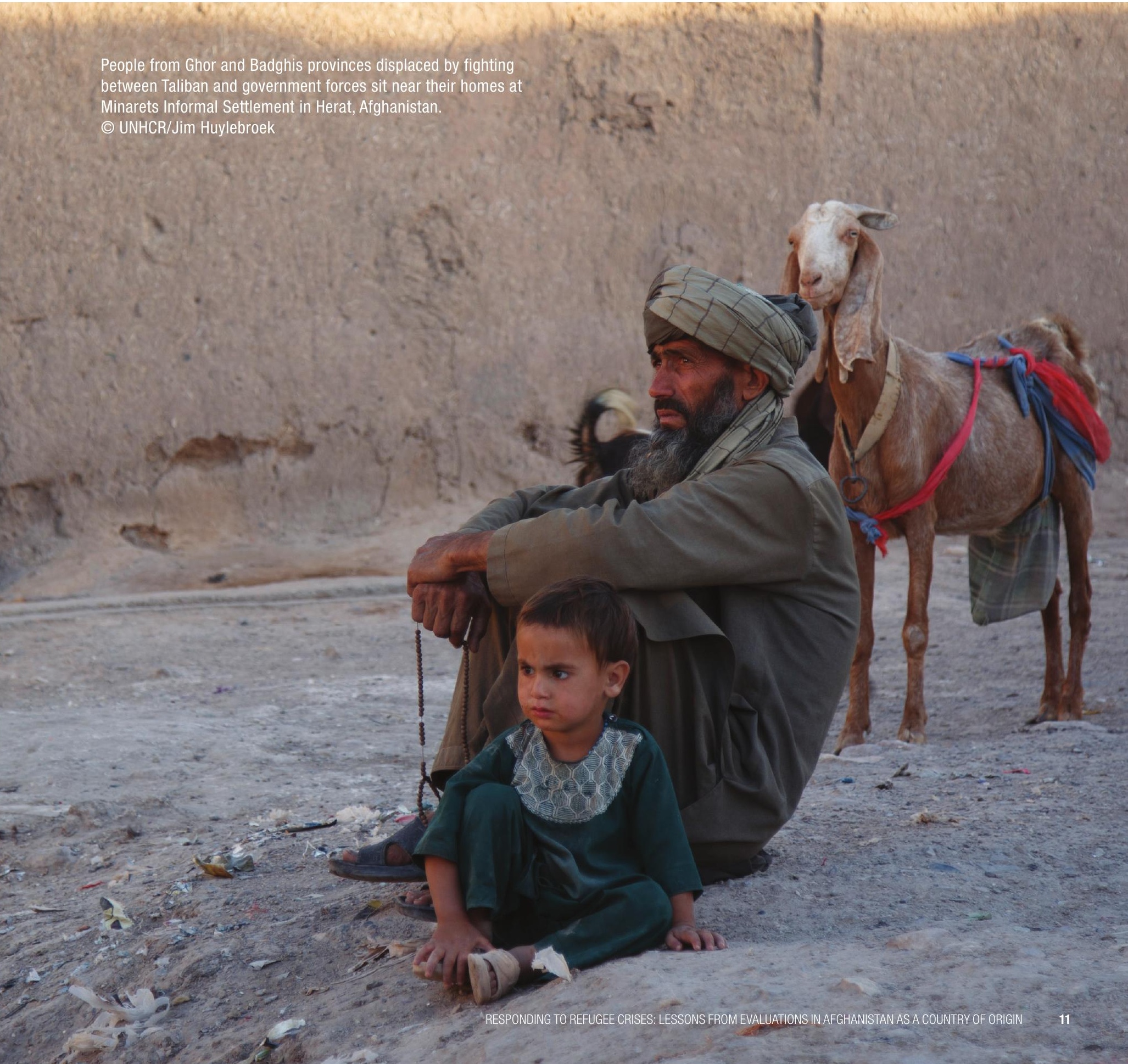
Understandably, there is considerable emphasis within the international development community on finding ways to reduce international refugee flows and to further lessen the displacement of people due to protracted crises. There is great attention on approaches designed to address the underlying drivers of conflict in countries such as Afghanistan, Syria, Iraq, Libya and South Sudan - countries where many refugees are forced to flee. This case study shows that international efforts to address the underlying causes of conflict in Afghanistan have not been as successful as initially hoped. The ramifications of these findings are important, given the significant amount of money that the international community has been spending in efforts to stabilise and reduce conflict in Afghanistan. Ultimately, the security conditions in Afghanistan have not improved to the extent that would allow Afghan refugees to return and ensure they would not face further violence. Experiences in Afghanistan suggest that, as of yet, there are no 'silver bullet' methods to achieve stabilization through combined military, diplomatic and development efforts to effectively prevent further displacement and reduce refugee outflows from unstable contexts.

The notion that it is possible to establish meaningful coherence among a number of contradictory goals may unintentionally enable those who are politically responsible to refrain from making clear strategic choices. Instead of having to prioritise and choose between different goals - and resources and methods - the coherence agenda promises that - if only we get our act together - it is possible to pursue many goals at the same time. Perhaps, it was this form of 'strategy' that failed in Afghanistan? [...] Based on the experience of Afghanistan this study suggests that future stabilisation interventions should take their starting point in the local context and from there seek to outline a possible political process that can lead the country away from fragility and towards stability. Only on the basis of such an analysis can meaningful decisions be made about the specific combination of international instruments and the degree to which these instruments need to go hand-in-hand in the field in order to succeed. The nexus between security and development does not only imply that lasting peace cannot be achieved without development; it also indicates that sustainable development cannot be pursued in the midst of ongoing war.

Louise Riis Andersen, International Lessons from Integrated Approaches in Afghanistan, 2016, Danish Institute for International Studies: 10. 


\section{Research notes and citations}

1 UNHCR, 2016: 16

2 lbid.

3 Internal Displacement Monitoring Centre, 2012, and IOM, 2016: 6

4 IOM, 2016

5 Internal Displacement Monitoring Centre, 2012, and IOM, 2016: 25

6 Ahmadi and Lakhani, 2016

7 Duenwald and Talishli, 2017

8 UNHCR, 2017

9 OECD, 2016

10 BBC, 2016. See also SIGAR interactive funding tables www.sigar.mil/quarterlyreports/ fundingtables/.

11 SIGAR, 2016a: 65

12 Emmott and Shalizi, 2016; Euranet Plus News Agency, 2016

13 European Union and Government of Afghanistan, 2016; Afghanistan Analysts Network, 2016; Euranet Plus News Agency, 2016

14 Papademetriou and Fratzke, 2016

15 Stepputat and Greenwood, 2013

16 For more information on the establishment of PRTs, see McNerney, 2005

17 See, for example, Bennett et al., 2009: "DFID's perception of Quick Impact Projects (QIPS) in Helmand as being "rapidly implemented projects that serve as down payments on promises of political and economic progress" was challenged recently by an independent evaluation commissioned by the Stabilisation Unit".

18 Stepputat and Greenwood, 2013: 28

19 lbid.
20 See also USAID, 2016: 10

21 Stepputat and Greenwood, 2013: 30; Bennett et al., 2009; Australian Civil-Military Centre, 2016: 36

22 Ibid. See also USAID, 2006.

23 Davies et al., 2007: 45

24 Stepputat and Greenwood, 2013:33. For further discussion on how the military-development boundaries may have been blurred deliberately, see Wilkens, 2016. On the issue of sustainability, see Davies et al., 2007: 22 and DFATD, 2015: 4.

25 Ministry of Foreign Affairs of Denmark, 2012: 38

26 CMI, 2016

27 Ibid.

28 DFATD, 2015: 4

29 Ibid.

30 Stepputat and Greenwood, 2013; Ministry of Foreign Affairs of Denmark, 2012: 39; and Wilkens, 2016. For a discussion of how military actors sought to gain access to humanitarian and development funds as "carrots", see also McNerney, 2005: 41.

31 DFATD, 2015: 6

32 USAID, 2006: 10

33 Stepputat and Greenwood, 2013: 41

34 CMI, 2016

35 Australian Civil-Military Centre, 2016: 28

36 Ibid.: 29

37 See, for instance, Bennett et al., 2009: XX

38 Stepputat and Greenwood, 2013: 40 and USAID/MSI, 2015

39 The MISTI project included USD 21 million in funding over three years from March 2012 to 2015 , with the aim of creating a community of practice for stabilisation monitoring and evaluation and learning, through the creation of "rigorously defined indicators, high standards for data verification and data quality". It also aimed to "create stability indicators and measure change over time to evaluate programme performance and impacts and be able to communication on best practices and lessons learned". See USAID/MSI, 2015: 1

40 USAID/MSI, 2015: 3

41 Ibid.: 6-7

42 Ibid.

43 Ibid: 9

44 Ibid.: 15

45 Ibid.: 12

46 Ibid.: 13

47 lbid.: 4

48 Ibid.: 16

49 DFATD, 2015: 3

50 For instance, see discussion in Australian Civil-Military Centre, 2016: 35-37

51 USAID, 2016: 42

52 USAID/MSI, 2015: 8 and 15

53 USAID, 2009: 9

54 Australian Civil-Military Centre, 2016: 35

55 lbid.

56 Ibid.: 36

57 SIGAR, 2016b: i

58 Parker, 2013: 1

59 Stepputat and Greenwood, 2013: 6

60 McNerney, 2005: 38 and Davies et al., 2007: 45 


\section{References}

Afghanistan Analysts Network (2016), "EU and Afghanistan get deal on migrants: Disagreements, pressure and last minute politics", Afghanistan Analysts Network, 6 October 2016.

Ahmadi, B. and S. Lakhani (2016), "The forced return of Afghan refugees and implications for stability", PeaceBrief No. 199, United States Institute of Peace, Washington, DC, https:// www.usip.org/publications/2016/01/ forced-return-afghan-refugees-andimplications-stability.

Andersen, L. R. (2016), Afghanistan Lessons Identified 2001-14 Part I, International Lessons from Integrated Approaches in Afghanistan, Afghanistan Lessons Identified 2001-14 Part I, Danish Institute for International Studies, Copenhagen, Denmark.

Australian Civil-Military Centre (2016), Afghanistan: Lessons from Australia's Whole-of-Government Mission, commissioned by the Australian Department of Defence in co-ordination with the Department of Foreign Affairs and Trade and the Australian Federal Police, www.acmc.gov.au/afghanistan/.

BBC News (2016), "Afghanistan aid: Donors promise \$15.2bn in Brussels", 5 October 2016, www.bbc.com/news/ world-asia-37560704 (accessed 8 February 2017).

Bennett, J. et al. (2009), "Country programme evaluation Afghanistan, Evaluation Report EV696, ITAD Ltd., commission by Department for International Development UK (DFID), www.oecd.org/countries/afghanistan/47107291.pdf.

Center for Complex Operations (CCO) (2011), "Sharing lessons on the conduct and design of stability operations", Workshop Report of the 7th International Lessons Learned Conference for Practitioners and Policy Makers, 30 November 2 December, 2011, CCO, National Defense University, Washington, DC.
Center for Global Development/ International Rescue Committee (2017), Refugee Compacts: Addressing the Crisis of Protracted Displacement, Final Report of the Forced Displacement and Development Study Group, Washington, DC/New York, www. cgdev.org/sites/default/files/RefugeeCompacts-Report.pdf.

Davies, A. et al. (2007), "Finnish aid to Afghanistan: Evaluation report", commissioned by Department for Development Policy, Ministry for Foreign Affairs of Finland, http:// formin.finland.fi/public/download. aspx?ID=28702\&GUID=3914c1f05b7b-44b3-9339-71217e8b9f84.

de Coning, C. et al. (2009), Norway's Whole-of-Government Approach and its Engagement with Afghanistan, Security in Practice 8, Norwegian Institute of International Affairs, Department of Security and Conflict Management, Oslo, www.oecd.org/ dac/evaluation/dcdndep/47107380. pdf.

DEval (2015), "Evaluations of German development cooperation with Afghanistan", DEval Policy Brief 1/2015, German Institute for Development Evaluation, Bonn, www.deval.org/files/content/Dateien/ Evaluierung/Policy\%20Briefs/DEval_Policy\%20Brief_01_Afghanistan_en.pdf.

DFATD (Department of Foreign Affairs, Trade and Development Canada) (2015), Synthesis Report -Summative Evaluation of Canada's Afghanistan Development Program, Fiscal year 2004-2005 to 2012-2013", www. international.gc.ca/department-ministere/assets/pdfs/evaluation/2015/ adp-pda-eng.pdf.

Duenwald, C. and F. Talishli (2017), "Return of Afghan refugees to Afghanistan surges as country copes to rebuild", International Monetary Fund News website, www.imf.org/en/News/ Articles/2017/01/26/NA012617-Return-of-Afghan-Refugees-to-Afghanistan-Surges-Country-Copes-Rebuild (accessed on 6 February 2017).
Emmott, R. and H. Shalizi (2016), "World powers pledge $\$ 15$ billion for Afghanistan, EU seeks peace", 6 October 2016, Reuters News Service, www.reuters.com/article/usafghanistan-aid-idUSKCN1250UI?il=0 (accessed on 8 February 2017).

Euranet Plus News Agency (2016), "Afghanistan wins aid pledges after sealing EU migrant deal", 5 October 2016, http://euranetplus-inside.eu/ afghanistan-wins-aid-pledges-aftersealing-eu-migrant-deal/ (accessed on 8 February 2017).

European Union and Government of Afghanistan (2016), "Joint Way Forward on migration issues between Afghanistan and the EU", www.asktheeu.org/fr/request/3420/ response/11692/attach/4/JWF\%20 FINAL\%20VERSION.pdf (accessed 8 February 2017).

Friis K. and S. Rehman (eds.) (2010), Nordic Approaches to Whole-of-Government - in Afghanistan and beyond, Security in Practice No. 6, Norwegian Institute of International Affairs, Oslo, www.fhs.se/Documents/Externwebben/forskning/Forskningsprojekt/ Ledningsvetenskap/FCP2014/nordicapproaches-to-whole-of-government. pdf.

Internal Displacement Monitoring Centre (2012), "Afghanistan: Durable solutions far from reach amid escalating conflict", Internal Displacement Monitoring Centre of the Norwegian Refugee Council, Geneva.

IOM (2016), "Migration flows from Afghanistan and Pakistan towards Europe: Understanding data-gaps and recommendations", Displacement Tracking Matrix (DTM), Desk Review Report, International Organization for Migration, https://afghanistan. iom.int/sites/default/files/Reports/ dtm_2016_-_migration_flows_from_ afghanistan_and_pakistan_towards_ europe._understanding_data_gaps_ and_recommandations.pdf. 
Marchand, K. et al. (2014), Afghanistan: Migration Profile, Prepared for the International Organization for Migration (IOM), Kabul, http://publications.iom.int/fr/system/files/pdf/mp_afghanistan_0.pdf.

Mazzetti, M. and E. Schmitt (2015), "Obama's 'boots on the ground': U.S. Special Forces are sent to tackle global threats", 27 December 2015.

McNerney, M. J. (2005), "Stabilization and reconstruction in Afghanistan: Are PRTs a model or a muddle", Parameters, Winter 2005-06. U.S. Army War College, Strategic Studies Institute, http:// strategicstudiesinstitute.army.mil/pubs/ parameters/articles/05winter/mcnerney. pdf (accessed 7 February 2017).

Ministry of Foreign Affairs of Denmark (2012), Evaluation of Danish Development Support to Afghanistan, Evaluation Department, International Development Cooperation, DANIDA, Copenhagen, Demark, https://www.oecd.org/countries/ afghanistan/Afghanistan--Final-WEB.pdf.

NORAD (2012), Evaluation of Norwegian Development Cooperation with Afghanistan 2001-2011, Evaluation Department, Norwegian Agency for Development Cooperation (NORAD), Olso, www.oecd. org/countries/afghanistan/50586740.pdf.

NOU (2016), En god alliert-Norge I Afghanistan 2001-2014, Departementenes sikkerhets- og serviceorganisasjonlnformasjonsforvaltning, Oslo, Norway. www.regjeringen.no/contentassets/09faceca09 9c4b8bac85ca8495e12d2d/no/pdfs/ nou201620160008000dddpdfs.pdf.

OECD (2016), Development Aid at a Glance Statistics by Region: Asia 2016 Edition, OECD, Paris, http://www.oecd. org/dac/stats/documentupload/4\%20 Asia\%20-\%20Development $\% 20$ Aid $\% 20$ at\%20a\%20Glance\%202016.pdf.
Papademetriou, D. G. and Fratzke (2016), "Top 10 of 2016 Issue \#1: Dawn of new migration reality brings focus on borders, returns, and integration" 20 December 2016, The Online Journal, Migration Policy Institute, Washington, DC, www.migrationpolicy.org/article/top10-2016-issue-1-dawn-new-migrationreality-brings-focus-borders-returnsand.

Parker, N. (2013), Lessons Learned: USAID Perspectives on the Experience with Provincial Reconstruction Teams (PRTs) in Afghanistan, USAID, http://pdf. usaid.gov/pdf_docs/pnaec659.pdf.

Poole, L. (2011), "Afghanistan: Tracking major resources flows", Global Humanitarian Assistance Development Initiatives, Somerset, UK, http:// afghandata.org:8080/xmlui/bitstream/ handle/azu/15274/azu_acku_pamphlet_hv555_a3_p66_2011_w. pdf? sequence=18isAllowed=y.

Reuters News Service (2016), "Norway to send 60 troops to train Syrian fighters", 2 May 2016, www.reuters.com/article/ us-norway-syria-military-idUSKCNOXT1L2 (accessed 7 February 2017).

Samuel Hall Consulting (2014), Evaluating IOM's Return and Reintegration Activities for Returnees and Other Displaced Populations: Afghanistan, commissioned by the International Organization for Migration (IOM), Kabul, http://afghanistan.iom.int/evaluatingiom\%E2\%80\%99s-return-and-reintegration-activities-returnees-and-otherdisplaced-populations.

SIGAR (2016a), Quarterly Report to the United States Congress, Congressional Report, 30 July 2016, Special Inspector General for Afghanistan Reconstruction, Washington, DC, https://www.sigar.mil/ pdf/quarterlyreports/2016-07-30qr.pdf.

SIGAR (2016b), Corruption in Conflict: Lessons from the U.S. Experience in Afghanistan, Special Inspector General for Afghanistan Reconstruction, Washington, DC. www.sigar.mil/pdf/lessonslearned/ SIGAR-16-58-LL.pdf.
SIGAR (2016c), Lessons from the Coalition: International Experiences from the Afghanistan Reconstruction, Conference Report, 19-20 April 2016, Special Inspector General for Afghanistan Reconstruction, Washington, DC, www. sigar.mil/pdf/lessonslearned/SIGAR-1659-LL.pdf.

Stepputat, F. and L. Greenwood (2013), Whole-of-Government Approaches to Fragile States and Situations, Danish Institute for International Studies (DIIS), Copenhagen, http://pure.diis.dk/ws/ files/46447/DIIS_RP2013_25_Stepputat_Web.pdf.

UNHCR (2017), "Tough choices for Afghan refugees returning home after years in exile", UNHCR News Brief, 3 February 2017, www.unhcr.org/news/ briefing/2017/2/589453557/toughchoices-afghan-refugees-returninghome-years-exile.html (accessed 7 February 2017).

UNHCR (2016), Global Trends: Forced Displacement in 2015, UNHCR, www.unhcr.org/576408cd7.pdf.

USAID/MSI (2015), MISTI Stabilization Trends and Impact Evaluation Survey, Analytical Report, Wave 5: Sep 28-Nov 3, 2014, USAID/Management Systems International, Washington, DC/ Arlington, VA, pdf.usaid.gov/pdf_docs/pa00ks3x. pdf.

USAID (2016), Meta-analysis of Final Evaluations of USAID/Afghanistan Projects, 2010-2015, USAID, Washington, DC, pdf.usaid.gov/pdf_docs/pa00m8b2. pdf.

USAID (2009), Assessment of Corruption in Afghanistan, USAID, Washington, DC, pdf.usaid.gov/pdf_docs/Pnad0248.pdf.

USAID (2006), Provincial Reconstruction Teams in Afghanistan: An Interagency Assessment, PN-ADG-252, USAID, Washington, DC, pdf.usaid.gov/pdf_docs/ Pnadg252.pdf. 


\section{References}

US Army (2011), Afghanistan Provincial Reconstruction Team Handbook, Center for Army Lessons Learned, http://usacac. army.mil/sites/default/files/publications/11-16.pdf.

US Army (2010) Assessments and Measures of Effectiveness in Stability Operations Handbook, Center for Army Lessons Learned, www.globalsecurity. org/military/library/report/call/call_1041.htm.

US GAO (2011a), "Afghanistan: Actions needed to improve accountability of U.S. assistance to Afghanistan government", GAO 11-710, US Government Accountability Office, Washington, DC, www.gao. gov/new.items/d11710.pdf.
US GA0 (2011b), "Afghanistan's donor dependence", GA0 11-948R, US Government Accountability Office, Washington, DC, http://www.gao.gov/products/GAO11-948R.

US GAO (2010a), "Afghanistan development: USAID continues to face challenges in managing and overseeing U.S. Development Assistance Programs", US Government Accountability Office, Washington, DC, http://www.gao.gov/ assets/100/96809.pdf.

US GAO (2010b), 'The strategic framework for U.S. efforts in Afghanistan", US Government Accountability Office, Washington, DC, http://www.gao.gov/ assets/100/96809.pdf.
Wilkens, A. (2016), "To say it like it is: Norway's evaluation of its part in the international intervention", 23 August 2016, Afghan Analysts Network, www. afghanistan-analysts.org/to-say-it-likeit-is-norways-evaluation-of-its-part-inthe-international-intervention/.

World Bank (2016), Afghanistan Development Update, World Bank, Washington, DC, openknowledge.worldbank.org/ handle/10986/24396.

World Bank (2012), Afghanistan Country Program Evaluation 2002-2011, Independent Evaluation Group of the World Bank, Washington, DC, ieg.worldbankgroup.org/Data/reports/afghan_eval_full. pdf. 


\section{Responding to Refugee Crises: \\ Lessons from evaluations in Afghanistan as a country of origin}

The OECD DAC Network on Development Evaluation is an international forum that brings together evaluation managers and specialists from development co-operation ministries and agencies in OECD DAC member countries and multilateral development insitutions. The network has been instrumental in developing key international norms and standards for evaluation.

Responding to Refugee Crises in Developing Countries: What Can We Learn From Evaluations? provides evidence from evaluations to feed into guidance on better programming that is being developed through the DAC Temporary Working Group on Refugees and Migration. The main working paper draws on evaluation findings to highlight key lessons and recommendations for positive change going forward. It is complemented by three case studies that look at how policy objectives have been implemented in specific country contexts. The working papers highlight the evaluation work of DAC members and aim to strengthen the evidence base to help improve responses to situations of displacement in developing countries.

Key topics covered in the working papers include: lessons on bridging the gap between humanitarian and development programming; efforts to strengthen international response to protracted crises; lessons on whole-of-government approaches in refugee contexts; learning from work in urban settings; improving access to employment and quality education; new financing mechanisms for refugee crises in middle income countries; and lessons on financing in response to the Syria crisis.

Working paper and case studies on Afghanistan, South Sudan and Ethiopia/Uganda can be found at: http://www.oecd.org/dac/evaluation/evaluating-refugee-migration.htm. 